\title{
Visual Agnosia
}

National Cancer Institute

\section{Source}

National Cancer Institute. Visual Agnosia. NCI Thesaurus. Code C35276.

An inability to recognize or interpret objects by sight. 